\title{
COMMUNITIES OF THE AIR
}





\section{COMMUNIIIES OF THE AIR}

RADIO CENTURY, RADIO CULTURE

EDITED BY SUSAN MERRILL SQUIER

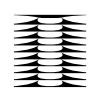

DUKE UNIVERSITY PRESS

DURHAM AND LONDON 
(C) 2003 Duke University Press

All rights reserved. Printed in the United

States of America on acid-free paper $\infty$ Designed by

Amy Ruth Buchanan. Typeset in Minion by Keystone

Typesetting, Inc. Library of Congress Cataloging-

in-Publication Data appear on the last printed

page of this book. 
To the radio lovers:

JDS (The Shadow knows),

CCS and RDS (ввс World Service),

NCBS (кото) and VLS (KDNK)

To the Society for Literature and Science,

a good community in which to think about

communities of the air.

And to Gowen, Caitlin, and Toby,

for sharing the same frequency

for so many years. 
